УДК 792.82:7.041]:7.071.1(479.25) Харатян

DOI: 10.31866/2616-7646.4.1.2021.236217

\title{
ЖАНР ПОРТРЕТА В ТВОРЧОСТІ ХОРЕОГРАФА РУДОЛЬФА ХАРАТЯНА
}

\author{
Саргсян Назенік Гагіківна, \\ доктор мистецтвознавства, провідний науковий співробітник, \\ Інститут мистецтв Національної академії наук \\ Республіки Вірменія, Відділ театру, \\ Єреван, Республіка Вірменія, \\ https://orcid.org/0000-0001-6926-1047, \\ nazeniksdagmail.com
}

\begin{abstract}
Мета статті - обгрунтувати правомірність уведення в галузь дансологіі поняття «жанр портрета» на прикладі постановок балетмейстера Рудольфа Харатяна. Методологія. Шляхом мистецтвознавчого аналізу балетів хореографа Рудольфа Харатяна «Іпостасі», «Bachpassion» (Пристрасті Баха) i «La Boheme», порівняння хореографічних рішень жанру портрета в назвах балетів виявлено специфіку інтерпретації образів композиторів Моцарта і Баха, а також шансоньє Шарля Азнавура. Наукова новизна. Уперше на основі аналізу трьох балетів Рудольфа Харатяна в дансологію введено поняття «жанр портрета», під яким розуміємо хореографічний спектакль або окремий номер, героєм якого є історична особистість (а не вигаданий персонаж), представник мистецтва. Висновки. Жанр портрета не ідентичний такому в живопису або скульптурі, але ближчий до творів літератури чи кінематографу. У них, як і в хореографічній виставі, на перший план виходить не тільки той, про кого вони оповідають, а головне - як. У балеті «Іпостасі» переданий різноманітний духовний світ Моцарта - його іпостасі як образи дійових осіб створених ним опер. Вони то знаходяться з ним у повній гармонії, то співпереживають йому, то відриваються від свого творця. У «Ваchpassion», крім самого Баха, беруть участь ще 13 балерин і танцівників, але немає конкретних персонажів - таке образне рішення музичного світу Баха. $\mathrm{V}$ «La Boheme» дію конкретизовано - це шлях Шарля Азнавура до визнання, протее назвати балет сюжетним не можна. Це швидше портрет шансоньє в інтер'єрі Монмартра. У перспективі жанр портрета може бути розглянутий більш широко, як хореографічний спектакль або окремий номер, героєм якого є історична особистість (а не вигаданий персонаж), безвідносно до того, представник він мистецтва, політики, науки, духовенства та ін.
\end{abstract}

Ключові слова: жанр портрета в балеті; хореографічна інтерпретація; балетмейстер Рудольф Харатян; Моцарт; Бах; Шарль Азнавур. 


\section{ЖАНР ПОРТРЕТА В ТВОРЧЕСТВЕ ХОРЕОГРАФА РУДОЛЬФА ХАРАТЯНА}

\author{
Саргсян Назеник Гагиковна, \\ доктор искусствоведения, \\ ведущий научный сотрудник, \\ Институт искусств \\ Национальной академии наук \\ Республики Армения, Отдел театра, \\ Ереван, Республика Армения, \\ https://orcid.org/0000-0001-6926-1047, \\ nazeniksaिgmail.com
}

Цель статьи - обосновать правомерность введения в область дансологии понятия «жанр портрета» на примере постановок балетмейстера Рудольфа Харатяна. Методология. Путем искусствоведческого анализа балетов хореографа Рудольфа Харатяна «Ипостаси», «Bachpassion» (Страсти Баха) и «La Boheme», сравнения хореографических решений жанра портрета в названных балетах выявлено специфику интерпретации образов композиторов Моцарта и Баха, а также шансонье Шарля Азнавура. Научная новизна. Впервые на основе анализа трех балетов Рудольфа Харатяна в дансологию введено понятие «жанр портрета», под которым подразумеваем хореографический спектакль или отдельный номер, героем которого является историческая личность (а не вымышленный персонаж), представитель искусства. Выводы. Жанр портрета не идентичен таковому в живописи или скульптуре, но ближе к произведениям литературы или кинематографа. В них, как и в хореографическом спектакле, на первый план выходит не только тот, о ком они повествуют, а главное - как. В балете «Ипостаси» передан многообразный духовный мир Моцарта - его ипостаси, как образы действующих лиц, созданных им опер. Они то находятся с ним в полной гармонии, то сопереживают ему, то отторгаются от своего создателя. В «Bachpassion», кроме самого Баха, принимают участие еще 13 балерин и танцовщиков, но нет конкретных персонажей - такое образное решение музыкального мира Баха. B «La Boheme» действие конкретизировано - это путь Шар-

\section{THE PORTRAIT GENRE IN THE WORKS OF CHOREOGRAPHER RUDOLF KHARATYAN}

\author{
Nazenik Sargsyan, \\ Doctor of Arts, Leading Researcher, \\ Institute of Arts, \\ National Academy \\ of Sciences of the Republic of Armenia, \\ Theater Department, \\ Yerevan, Republic of Armenia, \\ https://orcid.org/0000-0001-6926-1047, \\ nazeniksagmail.com
}

The purpose of the article is to substantiate the validity of introducing the concept of 'portrait genre' into the field of danceology using the example of productions by choreographer Rudolf Kharatyan. Methodology. Through the art history analysis of choreographer Rudolf Kharatyan's ballets 'Hypostases', 'Bach Passion' (The Passion of Bach) and 'La Boheme', comparing the choreographic solutions of the portrait genre in these ballets, the specifics of the interpretation of the images of the composers Mozart and Bach, as well as the chansonnier Charles Aznavour were revealed. Scientific novelty. For the first time, based on the analysis of three ballets by Rudolf Kharatyan, the concept of 'portrait genre' was introduced into danceology, by which we mean a choreographic performance or a separate number, the hero of which is a historical person (and not a fictional character), a representative of art. Conclusions. The portrait genre is not identical to that in painting or sculpture, but closer to works of literature or cinema. In them, as in a choreographic performance, not only the one about whom they narrate comes to the fore, but most importantly - how. In the ballet 'Hypostases' the diverse spiritual world of Mozart, his hypostases as the images of the characters in the operas created by him are conveyed. They are in complete harmony with him, then they empathize with him, then they are rejected from their creator. In 'Bach Passion', besides Bach himself, thirteen more ballerinas and dancers take part, but there are no specific characters. This is the figurative decision of the musical world of Bach. In 
ля Азнавура к признанию, однако назвать балет сюжетным нельзя. Это скорее портрет шансонье в интерьере Монмартра. В перспективе жанр портрета может быть рассмотрен более широко, как хореографический спектакль или отдельный номер, героем которого является историческая личность (а не вымышленный персонаж), безотносительно к тому, представитель ли он искусства, политики, науки, духовенства и др.

Ключевые слова: жанр портрета в балете; хореографическая интерпретация; балетмейстер Рудольф Харатян; Моцарт; Бах; Шарль Азнавур.
'La Boheme', the action is concretized - this is Charles Aznavour's path to recognition, but the ballet cannot be called a story ballet. It is rather a portrait of a chansonnier in the interior of Montmartre. In the future, the portrait genre can be considered more broadly as a choreographic performance or a separate number, the hero of which is a historical person (and not a fictional character), regardless of whether he is a representative of art, politics, science, clergy, etc.

Keywords: portrait genre in ballet; choreographic interpretation; choreographer Rudolf Kharatyan; Mozart; Bach; Charles Aznavour.

Актуальность темы исследования. Под жанром портрета в танцевальном искусстве мы подразумеваем хореографический спектакль или отдельный номер, героем которого является историческая личность (а не вымышленный персонаж), представитель искусства.

Исследование специфики творчества армянских хореографов XX - начала XXI вв. - одна из важных задач сегодняшней хореологии. И исследование творчества одного из наиболее ярких представителей армянской хореографии Рудольфа Харатяна очень актуально.

Естественно, жанр портрета не идентичен таковому в живописи или скульптуpe, но ближе к произведениям литературы или кинематографа. В них, как и в хореографическом спектакле, на первый план выходит не только тот, о ком они повествуют, а главное - как. При сопоставлении фильма С. Параджанова «цет граната» (о поэте Саят-Нова) с многочисленными фильмами, подробно излагающими биографии Паганини, Листа, Чайковского и других, разница налицо.

Анализ последних исследований и публикаций. В балетоведческой литературе проблема жанров поднималась неоднократно, в частности в трудах В. Ванслова (1980), М. Загайкевич (1978), П. Карпа (1990) и др. Но ни в последних исследованиях и публикациях, ни в более ранних, в которых велись поиски решения проблемы системы балетных жанров, мы не нашли ничего касающегося постановки или исследования такого понятия, как «жанр портрета в танцевальном искусстве».

Ранее мы уже обращались к творчеству Харатяна (Саргсян, 2017а). Однако выбранный ракурс исследования требует углубления поисков. Биографию Рудольфа Харатяна также можно найти на сайте «Энциклопедия фонда “Хайазг”» ("Харатян Рудольф Гургенович", 2013). О балетах «Bachpassion» и «La Boheme» нами ранее написаны рецензии в газете «Голос Армении» (Саргсян, 2010, 2017b).

Цель исследования - обосновать правомерность введения в область дансологии понятия «жанр портрета» на примере постановок балетмейстера Рудольфа Харатяна.

Материалом исследования являются балеты народного артиста Армении, хореографа Рудольфа Харатяна, а именно: сценарий балета «Ипостаси» (иначе 
«Моцартиана») и непосредственно балет (воспоминания о его хореографическом воплощении), а также балеты «Bachpassion» (Страсти Баха) и «La Boheme» на сцене и в видеозаписях, что позволило выявить специфику интерпретации образов композиторов (Моцарта, Баха) и шансонье Шарля Азнавура.

Изложение основного материала. Имя народного артиста Армении Рудольфа Харатяна широкой публике, а особенно любителям балета, известно очень давно. По крайней мере с того момента, как он появился в 1966 г. в отчетно-выпускном концерте Ереванского хореографического училища (ныне -Государственный хореографический колледж) в партии Солора в акте «Тени» из балета Л. Минкуса «Баядерка» в паре с Надеждой Куропятник (впоследствие - Надежда Харатян), вскоре ставшей его женой.

Многие годы педагоги училища обходили общеобразовательные школы и предлагали детям 9-10 лет, наделенным хорошими данными для танцовщика (или балерины), прийти на приемные экзамены в училище. Конечно же не все приходили. Но Рудольф пришел и прошел вступительные экзамены. Так начался его путь в балете, который уже длится более 60-ти лет. Сначала обучение в классе народного артиста Российской Федерации Максима Мартиросяна, подготовившего целую плеяду балерин и танцовщиков, которые многие годы были солистами и ведущими танцовщиками театра им. Ал. Спендиарова, а затем стали хореографами и прекрасными организаторами танцевальных коллективов, педагогами и репетиторами.

По окончании училища Рудольф в течение года проходит стажировку в Ленинградском хореографическом училище у знаменитого педагога Александра Ивановича Пушкина, который воспитал ведущих танцовщиков для различных театров оперы и балета на территории СССР, а некоторые блистали на международной сцене, как, например, Михаил Барышников (Харатян и Барышников учились в одном классе).

По возвращении в Ереван началась стремительная карьера Харатяна как премьера театра оперы и балета. Он исполнил заглавные роли практически во всех балетах, которые шли с конца 60-х до конца 80-х годов XX в. Это были и партии в классических балетах - Альберт («Жизель»), Зигфрид («Лебединое озеро»), Базиль и Эспада («Дон Кихот»), и в постановках армянских балетмейстеров. Среди них особо отметим «Антуни» в постановке Максима Мартиросяна, Меджнун в балете «Лейли и Меджнун», Ара Прекрасный в балете «Ара Прекрасный и Шамирам» в постановке заслуженного деятеля искусств Ашота Асатуряна, Спартак и Влюбленный юноша в «Болеро» в постановке народного артиста Латвии и Армении Евгения Чанги и Ромео в «Ромео и Джульетте» в постановке Олега Виноградова и др.

60-80-е годы XX в. принято называть «золотым веком» армянского балета и в аспекте богатого и разнообразного репертуара, и по количеству постановок, и гастролей армянского балета, а также отдельных ведущих танцовщиков как на подмостках балетных театров Москвы, Ленинграда и различных союзных республик, так и за рубежом. Во всей этой художественной жизни Харатян принял непосредственное участие. В те же годы он начал свою преподавательскую деятельность - пробовал силы и как хореограф.

Зрители надолго запомнили Харатяна-танцовщика, отличавшегося прекрасным владением техникой классического, характерного и современного танца, 
блестяще владеющего техникой поддержки, необычайно гибкого, пластичного, а главное - создавшего впечатляющие и многогранные образы.

В одном из предыдущих исследований мы представили балет Эд. Оганесяна «Антуни» (Саргсян, 2019). Однако нами был дан только анализ хореографической интерпретации балетмейстером Максимом Мартиросяном образа Архимандрита Комитаса, мы не обращались к исполнителям главных партий. Теперь время подчеркнуть, что образ героя был создан специально для Рудольфа Харатяна, с ориентированием на своеобразие его актерского дарования, на виртуозное владение техникой танца, и на своеобразную пластичность.

Уже в 1979 г. Харатян сформировал труппу «Балет армянского телевидения», в деятельности которой проявились главные тенденции, определяющие его творческий почерк. Во-первых, ставка на молодых исполнителей, подбор хороших специалистов - педагогов-репетиторов, аккомпаниаторов. Многие балерины и танцовщики, только что окончившие училище, тянулись к нему. Те молодые исполнители, которые в труппе театра танцевали в кордебалете или в отдельных второстепенных ролях, у Харатяна получали и заглавные роли в его постановках, а также сольные номера из классических балетов, тех, которые никогда не шли на нашей сцене. Уже в те годы в постановках самого Харатяна можно было отметить такие черты, как концептуальность, лаконичность высказывания, использование иконографических и символических знаков.

За годы своей деятельности «Балет армянского телевидения» представил следующие постановки Харатяна: «Ипостаси» - балет о Моцарте на музыку Моцарта, балет «Pasd'action» по мотивам «Гамлета» У. Шекспира. В 1988 г. этот балет был запечатлен в форме фильма-балета в Москве - как образец советского хореографического авангарда. Балет «Па д’аксьон» поставлен на музыку двух композиторов XX в. - Г. Яблонского и Е. Ульриха и «Аве Марии» композитора XVI в. Дж. Каччини. Далее - «Артавазд и Клеопатра» на музыку третьей симфонии Авета Тертеряна, телебалеты «Ануш» на подборку из армянской народной музыки (Саргсян, 2020) и др. В 1986 г. Р. Харатян приглашен в монреальский «Les Ballets Classiques de Montreal». В то же время, по приглашению танцевальной труппы «Наири» армянского культурного союза «Текеян», он берет на себя обязанности художественного руководителя и воплощает три различные концертные программы. В 1991 г. он приглашен в США, где работал преподавателем классического танца в Академии балета им. Кирова в Вашингтоне до 1994 г. В 1999 г. основал балетную труппу «ARKA» в Вашингтоне.

В 2009-2014 гг. по приглашению Министерства культуры Республики Армения Харатян исполнял обязанности главного хореографа Национального академического театра оперы и балета. За пять сезонов Рудольф Харатян пополнил репертуар новыми и классическими постановками, в том числе «Страсти по Баху», «Stabat Mater», «Болеро», «Ромео и Джульетта» и другие балетные постановки. В 2014-2017 гг. Р. Харатян - хореограф Национального академического театра оперы и балета, а в 2011 г. - основал Фонд развития «Балет 2021». За это время им был представлены ряд заметных постановок, среди которых отметим «Два солнца» (2015) и «La Boheme» (2017) о Шарле Азнавуре. В 2012 г. ему было присвоено звание народного артиста Республики Армения. В 2018 г. фонд «Балет 2021» 
открыл в Гюмри современный многофункциональный международный «Центр искусств Харатяна».

Харатян прекрасно проявил себя на поприще преподавателя классического танца. Он преподавал в Кировской академии балета (Вашингтон), Американском балетном театре, Бостонском балете, Вашингтонском балете, Молодежном балете Бразилии, танцевальной труппе Дебры Колкер, Школе искусств Северной Каролины и многих других. Также он работал в Школе искусств Дюка Эллингтона в Вашингтоне (округ Колумбия), Подготовительном центре Пибоди в Балтиморе, Les Ballets Classiquesde Montreal и Ballet Divertismento в Монреале.

Кроме того, Харатян является признанным художником. Его работы находятся в частных коллекциях США, Канады, Великобритании, Южной Африки и Армении.

Следует отметить, что Харатян единственный армянский балетмейстер, чей балет «Два солнца» («Two Suns») был показан по телеканалу «Mezzo» в начале 2020 г., также с ним заключен контракт на показ этого балета на пять лет.

Обратимся к трем балетам-портретам, созданным Рудольфом Харатяном «Ипостаси» или «Моцартиана» на музыку В. А. Моцарта, «Страсти Баха» и «La Boheme», героем которого является великий шансонье армянского происхождения Шарль Азнавур.

Ранее мы уже освещали балет «Два солнца» (Саргсян, 2017а). Отметим лишь, что балет был создан в 2015 г. фондом «Ballet 2021», основанном и возглавляемом Харатяном с 2011 г. Здесь выведены портреты великого поэта Григора Нарекаци, армянского средневекового выдающегося миниатюристаТороса Рослина, всемирно известного художника XX в. Аршила Горки (армянина по происхождению), а также мистика Георгия Гурджиева.

Все представленные балеты - это хореографические интерпретации жизни композиторов, поэтов, художников. В жанровом отношении по объему - одноактные и двухактные балеты. К специфике сценариев и особенностям хореографической лексики мы обратимся ниже.

«Ипостаси». Действующие лица: Тамино («Волшебная флейта»), он же Моцарт, Двойник, Черный человек, Констанца («Похищение из сераля»), Папагено («Волшебная флейта»), Памина («Волшебная флейта»), Фиордилиджи («Так поступают все»), Идамант («Идоменей»), Церлина («Дон Жуан»).

В балете передан многообразный духовный мир Моцарта - его ипостаси, как образы действующих лиц созданных им опер. Они то находятся с ним в полной гармонии, то сопереживают ему, то отторгаются от своего создателя.

Балет скомпонован из частей трех произведений Моцарта - первой части Сонаты № 11, второй части Концерта для фортепиано с оркестром № 23 и третья - Финала Октета для духовых инструментов - по типу своеобразного сонатно-симфонического цикла. Следует отметить, что Р. Харатян в подавляющем большинстве использует музыку «небалетного» жанра. Среди его многочисленных балетов и отдельных номеров толькотри или четыре поставлены на основе балетных партитур, в том числе «Ромео и Джульетта» С. Прокофьева (в 2011 г. на сцене Ереванского театра оперы и балета). В целом же им охвачен огромный круг от Перголези до современного композитора Ван Бода. От гимнов, распеваемых на заре христианства создателем армянского алфавита Месропом Маштоцем до композиторов конца XX в. - Эдгара Оганесяна и Авета Тертеряна. 
Возвращаясь к балету «Ипостаси», обратимся к соотношению музыкального и хореографического компонентов. Первая часть Сонаты № 11 написана в вариационной форме. А в хореографии - в изложении темы принимают участие все действующие лица, кроме Двойника и Черного человека. Тема сочетает элементы академического танца и менуэта. Далее каждая музыкальная вариация имеет форму хореографической вариации одного из оперных персонажей. Вторая часть хореографически интерпретируется как Моцарт - партия фортепиано, а другие действующие лица -оркестр. В третьей части - Финала Октета для духовых инструментов- запомнилось появление Черного человека на теме и его конфликт с Моцартом.

В «Bachpassion», кроме самого Баха, принимают участие еще 13 балерин и танцовщиков, но нет конкретных персонажей. Это исключительно музыкальный мир Баха. Премьера балета состоялась 22 июня 2002 г. в Kay Theater в Вашингтоне, а на сцене Ереванского театра оперы и балета - в 2010 г.

Вот что изложил Р. Харатьян в программе балета: «Бах жил, чтобы поклоняться Богу и писать музыку. Церковь сыграла ключевую роль в жизни Баха. Он был верующим, смиренно служил Господу, поклонялся Богу. Пересматривая свою жизнь, Бах однажды упомянул, что много работал. Доказательство тому - поразительное количество работ. Созданные Бахом ценности космические и вечные, музыка, которую он создал, основана на гармонии языка, вдохновении, духовном содержании.

«Страсти Баха» - одноактный балет для 14 танцовщиков: четыре мужчин и 10 женщин. Балет не описывает жизнь Баха, он не погружает нас в глубины его характера - это выражение страсти великого мастера. Сцена пуста, охватывая смысл бесконечного пространства. Простота костюмов танцоров свидетельствует о красоте тела, с помощью которого хореография создает визуальный образ архитектурной музыки Баха. Спектакль наполнен символами, которые откликаются на энергию и метафизическое воздействие музыки и придают ей глоток свежего воздуха. Бах везде. Энергия, исходящая от каждого танцовщика, - это истина красоты гармонии. И наконец Бах один. Его монолог - это новая спираль, путешествие в вечность» (перевод с армянского наш - Н. С.) (Национальный Академический театр оперы и балета, 2010).

«Страсти Баха»- хореографический образ Баха на его музыку. Если в балете «Ипостаси» все же можно было отметить некоторые биографические детали жизни Моцарта (в частности, появление Черного человека, как известно, заказавшего «Реквием» Моцарту и как бы прервавшего его земной путь и т.д.), то в балете «Страсти Баха» на биографию Баха нет и намёка. Это исключительно духовный мир музыки Баха, в каких-то фрагментах - полифонические принципы композиции, переданные визуально. Можно отметить множество жестов, движений, композиций-символов, однако их прочтение и наша интерпретация - предмет профессионального анализа. Этот балет также скомпонован из частей нескольких произведений Баха - «Магнификата», «Пассиона» и Концертов. Это балет с обобщенно-философской концепцией.

В аннотации Харатян предлагает свою интерпретацию действа. Однако возможны и другие интерпретации. Как трудно рассказать какое-либо серьезное музыкальное произведение, а тем более однозначно растолковать его, так и труд- 
но не только в балетах Харатяна, но и многих балетмейстеров XX-XXI веков, однозначно рассказать их содержание.

Обратимся к красному полотну. Длинное, широкое полотно, как действенный участник, проходит через весь балет «Страсти Баха». Однако здесь уже возможны разные интерпретации. Символизирует ли красное полотно «страсти» Баха или это дорога, линия судьбы Баха? В любом случае, представленный на суд зрителя балет Харатяна еще раз подтверждает мысль о том, что хореография, более чем какой-либо другой вид искусства, на сегодняшний день почти приравнивается к самому «абстрактному» из искусств - к классической музыке. Это балет с обобщенно-философской концепцией.

В. А. Моцарт, И. С. Бах, Св. Григорий Просветитель, Св. Григор Нарекаци... В 2017 г. список постановок Р. Харатяна пополнился еще одним балетом в жанре биографического балета или, точнее, балета-портрета. На сей раз его герой - великий шансонье Шарль Азнавур. Постановки такого жанра, осуществленные хореографом, можно условно разделить на два типа - балеты, в которых более или менее отражены биографические факты из жизни вышеперечисленных деятелей, и балеты, в которых образ героя воплощен обобщенно. В балете «La Boheme» эти два типа объединены. Здесь можно отметить и некоторые факты, почерпнутые из биографии Азнавура, и обобщенные иносказательные фрагменты.

Музыкальная партитура - 12 песен из репертуара Шансонье в его же исполнении (балет идет под фонограмму). Песни отобраны и расположены по принципу соответствия их содержания действиям и переживаниям героя - от появления честолюбивого молодого человека в средоточии художественной жизни Парижа - на Монмартре, его неуклонный путь по ступеням славы - от признания до триумфа.

На первый взгляд эта постановка Харатяна отличается от других его балетов. Здесь нет символических знаков и композиций, вклинивающихся и сочетающихся с элементами и композициями современного классического танца. Исключение - балет «La Revanchadel Tango». Однако постепенно вникая в детали и суть действия, начинаешь понимать, что все компоненты спектакля - сценография, тип использования сценического пространства, сценические атрибуты и, естественно, действующие лица - образы и пластика, отдельные движения - все функционально и несет определенную смысловую нагрузку.

Действие развивается в трех плоскостях. Сама сцена разделена на три части условно «партерную», далее, как бы второй приподнятый пласт и задник (об этом подробнее ниже). На плоскости партерной части развивается основное действие.

B постановке «La Boheme» задник сцены обыгран с тонким художественным пониманием. Легкий графический рисунок, освещение каким-либо цветом в основном является фоном и не мешает, а дополняет сценическое действие. Только в третьей и предпоследней сцене задник становится подвижным. В третьей сцене на Монмартре, действие развивается как «трехголосное», трехслойное, на заднике калейдоскопически сменяются тени, исполняются парные танцы, чередующиеся с тенями пешеходов, падающих и взлетающих людей. В то же время на «партерной» и приподнятой сцене протекает пластический дуэт - герой внизу, а его возлюбленная на возвышенности. Постепенно тени исчезают, превращаясь в реальные фигуры, которые постепенно спускаются на основную сцену, в целом образуя переходящий из виртуального в реальный многоликий облик Монмартра. 
В предпоследней сцене на экран проецируется видеофрагмент - Шарль Азнавур, исполняющий песню -герой на сцене, обобщенно передающий смысл, содержание и образ песни.

Подлинная функция второй приподнятой плоскости проявляется в завершающей картине - это сцена на сцене, «театр внутри театра», где герой, достигший славы, раскланивается под аплодисменты и хореографически воплощает песню «La Boheme», a партерная сцена - это зал со зрителями. B конце герой спускается на основную сцену, где продолжает свое пластическое пение. В целом возникает ассоциация со знаменитым высказыванием Шекспира «Весь мир - театр, а люди в нем актеры...».

На сцене почти нет бутафории, за исключением второй сцены, где фигурирует кровать, но основным и также многофункциональным бутафорским реквизитом становятся стулья, которые то предстают как скамейки на Монмартре, то как зрительские кресла в зале. В восьмой сцене при помощи стульев представлена хорошо известная детская игра, когда стульев становится на один меньше, чем принимающих участие в игре - по знаку тот, кто не успел сесть, выбывает из игры. Побеждает последний, успевший сесть на последний стул. Итак, эта детская игра становится символическим действием борьбы за первенство, которое прошел великий шансонье.

Особо хочется отметить, что в балете нет кордебалета в его обычном понимании, т.е. сопровождающей танцы героев массы. Хотя в спектакле задействованы около 20-ти актеров, каждый из них персонифицирован. Иногда это очень маленькие эпизодичные персонажи, как велосипедист, катающиеся на роликах, акробаты, цветочница и т.д. Местами, объединяясь на одной сцене, все персонажи все же никогда не становятся сопровождающей массой, но создают облик многоликий богемы.

В целом балет решен языком современного классического балета, включая его формы дуэтов, трио, квартетов, монологов и тип «коды» - обычно финала классических балетов, где исполняются самые виртуозные pas. Однако эта «кода» расположена не в финале, как принято, а в середине (№ 7) балета. Впрочем, перестановка частей традиционных форм классического балета является одним их основных приемов, свойственных композициям, созданным Харатяном. Отметим также совмещение и чередование классических движений балета с акробатическими, включение своеобразной трактовки цыганского танца в эпизоде, где исполняется известная песня Азнавура - переработка романса «Две гитары».

Костюмы и сценография, выполненные Асмик Степанян, создают образ красочных гравюр, которые так присущи художникам Монмартра.

Научная новизна. Впервые на основе анализа трех балетов Рудольфа Харатяна в дансологию введено понятие «жанр портрета», под которым подразумеваем хореографический спектакль или отдельный номер, героем которого является историческая личность (а не вымышленный персонаж), представитель искусства.

Выводы. Жанр портрета не идентичен таковому в живописи или скульптуре, но ближе к произведениям литературы или кинематографа. В них, как и в хореографическом спектакле, на первый план выходит не только тот, о ком они повествуют, а главное - как. В балете «Ипостаси» в постановке балетмейстера Р. Харатяна передан многообразный духовный мир Моцарта - его ипостаси как об- 
разы действующих лиц созданных им опер. Они то находятся с ним в полной гармонии, то сопереживают ему, то отторгаются от своего создателя. В «Bachpassion», кроме самого Баха, принимают участие еще 13 балерин и танцовщиков, но нет конкретных персонажей. Это образное решение музыкального мира Баха. B «La Boheme» действие конкретизировано - это путь Шарля Азнавура к признанию, однако назвать балет сюжетным нельзя. Это скорее портрет шансонье в интерьере Монмартра.

В перспективе жанр портрета может быть рассмотрен более широко, как хореографический спектакль или отдельный номер, героем которого является историческая личность (а не вымышленный персонаж), безотносительно к тому, представитель ли он искусства, политики, науки, духовенства и др.

\section{список ссылок}

Ванслов В. (1980). Статьи о балете. Музыкально-эстетические проблемы балета. Музыка. Загайкевич, М. П. (1978). Драматургія балету. Наукова думка.

Карп, П. (1990). Балет и драма. Искусство.

Национальный Академический театр оперы и балета имени Ал. Спендиаряна. (2010). Bachpassion [Программа спектакля].

Саргсян, Н. (2010, 18 марта). Строгая красота и духовность - это такая редкость! Голос Армении.

Саргсян, Н. (2017a). Основные тенденции балетного искусства Армении XX - начала XXI веков (на примере творчества армянских хореографов) [Диссертация доктора искусствоведения]. Институт искусств Национальной академии наук Республики Армения, Ереван.

Саргсян, Н. (2017b, 6 января). Хореографический портрет великого шансонье. Голос Армении.

Саргсян, Н. (2019). К вопросу о хореографической интерпретации трагических событий в истории нации (на примере балета «Антуни» Эдгара Оганесяна в постановке хореографа Максима Мартиросяна). Танцювальні студіï, 2(1), 59-71. https://doi. org/10.31866/2616-7646.2.1.2019.172186.

Саргсян, Н. (2020). Проявление тенденций музыкального и хореографического искусств XX - начала XXI в произведениях по мотивам поэм Ованеса Туманяна. Танцювальні cmydii, 3(1), 58-70. https://doi.org/10.31866/2616-7646.3.1.2020.203950.

Харатян Рудольф Гургенович. (2013, 10 декабря). В Энциклопедия фонда «Хайазг». http:// ru.hayazg.info/Харатян_Рудольф_Гургенович.

\section{REFERENCES}

A. Spendiaryan Opera and Ballet National Academic Theatre. (2010). Bachpassion [Show program] [in Armenian].

Karp, P. (1990). Balet i Drama [Ballet and Drama]. Iskusstvo [in Russian].

Kharatyan Rudolf Gurgenovich. (2013, December 10). In Encyclopedia of the Hayazg Foundation. http://ru.hayazg.info/Харатян_Рудольф_Гургенович [in Russian].

Sargsyan, N. (2010, May 18). Strogaya Krasota i Dukhovnost' - Eto Takaya Redkost'! [Strict Beauty and Spirituality are So Rarity!] Golos Armenii [Voice of Armenia] [in Russian]. 
Sargsyan, N. (2017a). Osnovnye Tendentsii Baletnogo Iskusstva Armenii XX - Nachala XXI Vekov (na Primere Tvorchestva Armyanskikh Khoreografov) [The Main Trends in the Ballet Art of Armenia of the Twentieth - Beginning of the Twenty-First Centuries (on the Example of the Work of Armenian Choreographers)] [Doctoral Dissertation]. Institute of Arts, National Academy of Sciences of Republic of Armenia, Yerevan [in Russian].

Sargsyan, N. (2017b, January 6). Khoreograficheskii Portret Velikogo Shanson'e [Choreographic Portrait of the Great Singer]. Golos Armenii [Voice of Armenia] [in Russian].

Sargsyan, N. (2019). K Voprosu o Khoreograficheskoi Interpretatsii Tragicheskikh Sobytii v Istorii Natsii (na Primere Baleta "Antuni" Edgara Oganesyana v Postanovke Khoreografa Maksima Martirosyana) [To the Issue of Choreographic Interpretation of Tragic Events in the History of a Nation (on the Example of Edgar Hovhannisyan's "Antuni" Ballet Staged by Choreographer Maxim Martirosyan)]. Tantsiuvalni Studii [Dance Studies], 2(1), 59-71. https://doi.org/10.31866/2616-7646.2.1.2019.172186 [in Russian].

Sargsyan, N. (2020). Proyavlenie Tendentsii Muzykal'nogo i Khoreograficheskogo Iskusstv XX nachala XXI v Proizvedeniyakh po Motivam Poem Ovanesa Tumanyana [Manifestation of Trends in Musical and Choreographic Arts of the 20th and Early 21st Centuries in the Works Based on Hovhannes Tumanyan's Poems]. Tantsiuvalni Studii [Dance Studies], 3(1), 58-70. https://doi.org/10.31866/2616-7646.3.1.2020.203950 [in Russian].

Vanslov V. (1980). Stat'i o Balete. Muzykal'no-Esteticheskie Problemy Baleta [Articles about Ballet. Musical and Aesthetic Problems of Ballet]. Muzyka [in Russian].

Zahaikevych, M. (1978). Dramaturhiia Baletu [Ballet Drama]. Naukova dumka [in Ukrainian]. 